\title{
Oral health in female patients with eating disorders
}

\author{
Mateusz Mazurek ${ }^{1} \mathrm{~A}, \mathrm{~B}, \mathrm{C}$, Anna Szyszkowska ${ }^{2} \mathrm{~A}, \mathrm{D}$, \\ Agata Mazurek ${ }^{1} \mathrm{C}, \mathrm{D}$, Jolanta Szymańska ${ }^{3} \mathrm{D}, \mathrm{E}, \mathrm{F}$ \\ ${ }^{1}$ Dental Office, KOL-MED Medical Center, Tarnów, Poland \\ ${ }^{2}$ Chair and Department of Dental Surgery, Medical University of Lublin, Poland \\ ${ }^{3}$ Chair and Department of Paedodontics, Medical University of Lublin, Poland
}

\begin{abstract}
The study aimed to evaluate oral health in women with eating disorders. The clinical study covered 30 patients aged 14-36 years suffering from diagnosed eating disorders and treated in closed psychiatric institutions. The control group comprised 30 healthy women at the mean age corresponding to that of the patient group. No relationships were confirmed between eating disorders and the intensity of dental caries. Eating disorders contribute to increased loss of dental hard tissues. In women suffering from eating disorders non-specific lesions in oral cavity are more common than in healthy women.
\end{abstract}

Keywords: eating disorders, anorexia nervosa, bulimia nervosa, oral health

\section{Introduction}

Eating disorders are conditions characterized by restricted food intake or binge eating, and often by selfinduced vomiting. In addition they are having the potential to impair both physical health and psychosocial functioning [1].

\section{Aim}

The study aimed to evaluate oral health in women with eating disorders.

\section{Material and methods}

The survey study covered 30 patients aged 14-36 years suffering from diagnosed eating disorders and treated in closed psychiatric institutions. The patients were hospitalised in the Affective and Psychotic Disorders Clinic in Łódź, Poland, and the Clinical Ward at the Children's and Youth's Psychiatric Clinic in Cracow, Poland. The study was approved by the Bioethical Committee at the Medical University of Lublin and by the boards of directors and department heads of the respective hospitals. The control group consisted of 30 healthy women, the clients of the Dental Office at the KOL-MED Medical Center in Tarnów, Poland; the age of the controls corresponded to that of the patients.

In the clinical study, intensity of dental caries was assessed by applying the mean DMFT number and its elements: D - decayed teeth, M - missing teeth due to decay and F - filled teeth. Oral hygiene was evaluated using plaque index PI (Plaque Index) by Silness and Löe that allowed determining the thickness of residual plaque at the gingival margin, an indicator of plaque in the interdental spaces - API (Approximal Plaque Index) and OHI (Oral Hygiene Index) by Greene and Vermillion. Community Periodontal Index of Treatment Needs (CPITN) was also used. It allows determining the prophylactictreatment activities concerning periodontal diseases. Teeth wear was rated by using Smith and Knight index (TWI - Tooth Wear Index). Other lesions that were found during the dental examination were documented as well. The survey results were analysed statistically. The values of measurable parameters were represented as mean, median and standard deviation, and those immeasurable ones - as frequency and percentage. For unrelated attributes, Chi-square test for homogeneity was used to detect the differences between the compared groups. Chi-square test for independence was used to investigate the relationships between the tested attributes. The assumed level of significance $\mathrm{p}<0.05$ indicated the presence of statistically significant differences or correlations. STATISTICA 10.0 (StatSoft, Poland) software was used to prepare the database and perform statistical analyses.

\section{Results}

Research showed that in female patients the number of teeth with decay (D) and missed teeth (M) was the same as in women in the control group, and the number of filled teeth (F) was slightly lower compared with healthy women, and no statistically significant difference was confirmed (Table 1). 
Table 1. The number of D, M, F teeth, and DMFT index in patients and controls

\begin{tabular}{|l|c|c|c|c|}
\hline \multirow{2}{*}{ Variables } & Patients & Controls & \multirow{2}{*}{$\mathrm{Z}$} & \multirow{2}{*}{$\mathrm{p}$} \\
\cline { 2 - 3 } & Median & Median & & \\
\hline $\mathrm{D}$ & 1.00 & 1.00 & -0.82 & 0.41 \\
\hline $\mathrm{M}$ & 0.00 & 0.00 & 0.45 & 0.65 \\
\hline $\mathrm{F}$ & 6.00 & 7.00 & 1.38 & 0.17 \\
\hline DMFT & 9.00 & 9.00 & 0.64 & 0.52 \\
\hline
\end{tabular}

In terms of PI and API indices, there was no statistically significant difference between the female patients and a group of healthy women. The statistical analysis showed significant differences between the group of patients and healthy subjects in terms of $\mathrm{OHI}(\mathrm{p}=0.01)$ (Table 2).

Table 2. PI, API, and OHI index in patients and controls

\begin{tabular}{|l|c|c|c|c|}
\hline \multirow{2}{*}{ Variables } & Patients & Controls & \multirow{2}{*}{$\mathrm{Z}$} & \multirow{2}{*}{$\mathrm{p}$} \\
\cline { 2 - 3 } & Median & Median & & \\
\hline PI & 1.00 & 0.98 & 1.35 & 0.18 \\
\hline API & 0.40 & 0.40 & 0.55 & 0.58 \\
\hline OHI & 1.00 & 0.66 & 2.80 & $0.01^{*}$ \\
\hline
\end{tabular}

The study shows that in the studied patients bleeding during probing of periodontal pockets was more frequent compared with the control group $(66.67 \%$ vs. $56.67 \%$ ). The presence of plaque was observed in $36.67 \%$ of women from the control group and in $30 \%$ of female patients. The observed differences were not statistically significant $(p=0.695)$ (Table 3$)$.

Table 3. Community Periodontal Index of Treatment Needs (CPITN) in the studied groups

\begin{tabular}{|l|c|c|c|c|}
\hline \multirow{2}{*}{ CPITN } & \multicolumn{2}{|c|}{ Patients } & \multicolumn{2}{c|}{ Controls } \\
\cline { 2 - 5 } & $\mathrm{N}$ & $\%$ & $\mathrm{~N}$ & $\%$ \\
\hline 1 - bleeding during probing & 20 & 66.67 & 17 & 56.67 \\
\hline $\begin{array}{l}\text { 2 - supra- and subgingival } \\
\text { calculus }\end{array}$ & 9 & 30.00 & 11 & 36.67 \\
\hline $\begin{array}{l}\text { 3 - depth of gingival pocket } \\
\text { up to 5 mm or more }\end{array}$ & 1 & 3.33 & 2 & 6.67 \\
\hline
\end{tabular}

$\mathrm{Chi}^{2}=1.44 ; \mathrm{df}=3 ; \mathrm{p}=0.695$

Assessment of tooth wear showed that the TWI values were significantly higher in patients than in the control group. There were significant differences in the loss of dental hard tissues within the enamel $(p=0.001)$ and within the enamel with up to $1 / 3$ dentin exposure $(p=0.02)$. Differences between groups were not statistically significant $(p=0.36)$ for the loss of dental hard tissue within the enamel with dentin exposure of more than $1 / 3$ (Table 4 ).

In patients treated for eating disorders, angular cheilitis, cheilitis, salivary gland enlargement and other lesions - inflammation of the tongue, dry skin, dark circles under the eyes were found (Table 5). This type of lesions was not found during dental examination in the control group.
Table 4. Wear of teeth in the studied groups expressed by TWI index

\begin{tabular}{|l|c|c|c|c|}
\hline \multirow{2}{*}{ Type of wear } & Patients & Controls & $\mathrm{Z}$ & $\mathrm{p}$ \\
\cline { 2 - 4 } & Median & Median & & $0.001^{* * *}$ \\
\hline $\begin{array}{l}\text { Loss of enamel } \\
\text { surface }\end{array}$ & 10.00 & 2.00 & 4.65 & $0.02^{*}$ \\
\hline $\begin{array}{l}\text { Loss of enamel } \\
\text { with up to 1/3 } \\
\text { dentin exposure }\end{array}$ & 1.00 & 0.00 & 2.37 & 0.36 \\
\hline $\begin{array}{l}\text { Loss of enamel with } \\
\text { more than 1/3 } \\
\text { dentin exposure }\end{array}$ & 0.00 & 0.00 & 0.91 & 0.36 \\
\hline
\end{tabular}

Table 5. Lesions in patients with eating disorders

\begin{tabular}{|l|c|c|}
\hline \multirow{2}{*}{ Lesions } & \multicolumn{2}{|c|}{ Patients } \\
\cline { 2 - 3 } & $\mathrm{N}$ & $\%$ \\
\hline Angular cheilitis & 6 & 20.00 \\
\hline Cheilitis & 4 & 13.33 \\
\hline Enlargement of salivary glands & 5 & 16.67 \\
\hline $\begin{array}{l}\text { Other lesions (inflammation of the tongue, } \\
\text { dry skin, dark circles under the eyes ) }\end{array}$ & 14 & 46.67 \\
\hline
\end{tabular}

\section{Discussion}

In earlier international studies no relationship between the incidence of cavities from eating disorders in anorexia and bulimia were shown [2], or even a lower incidence of tooth decay in not vomiting anorexics was demonstrated, which was explained by a special attention to oral hygiene [3]. Also Polish studies conducted in 2005 by Rusyan et al. showed no relationship between eating disorders and carious disease. The average DMFT number was for patients suffering from anorexia 8.94, bulimia 8.60 and 8.32 for control group [4]. In other studies DMFT number was 11.4 in women suffering from bulimia and 9.35 in healthy subjects in control group [5]. Our study showed no relationship between eating disorders and severity of dental caries, which was also confirmed in research by Daszkowska et al., who did not show any significant correlations between the incidence of caries and the DMFT number in patients with anorexia and bulimia [6].

By analyzing the results of our research on the oral hygiene in patients with eating disorders compared to healthy subjects, more residual plaque at the gingival margin and a similar amount of plaque in the interdental spaces and poorer oral hygiene was observed. However, the prophylactic-treatment needs of periodontal diseases turned out to be similar. They should include preventive measures in the form of oral instruction, professional removal of supra- and subgingival plaque and tartar, and with regard to individuals - analyzing the periodontal condition and offering specialist consultations.

Wear of hard tissues of the teeth of erosion-abrasive type is considered a significant lesion in the exploratory diagnosis of bulimia nervosa $[7,8]$. Based on the criteria of tooth wear index (TWI), statistically significant differences in the incidence of enamel and dentin wear between 
patients with bulimia (24\%) and female patients in the control group (9\%) were confirmed [7]. Statistically significant differences as to the number of worn teeth between the study group $(7.69 \pm 2.62)$ and the healthy controls (4.48 \pm 1.9 ) were also demonstrated [8]. In our research, we demonstrated a greater severity of the loss of dental hard tissues in women with eating disorders compared to women in the control group.

When referring to the incidence of lesions in the oral cavity in women with eating disorders, it should be noted that the percentage of people affected by the changes was different compared with the results obtained by Paszyńska et al. [9]. In the cited studies, inflammation of the corners of the lips occurred in $12.9 \%$ of patients with anorexia nervosa and this proportion was lower than in our study, while exfoliative cheilitis affected $41.9 \%$, and this percentage was higher than in the present study. Exfoliation of the lining of the lips may be, among others, a consequence of dehydration and reduced salivary flow, deficiency of micronutrients (such as vitamins A and B) associated with periods of starvation, and the result of parafunctions as habitual biting of lips against stress [10]. In our research, we confirmed in patients a lower incidence of atrophic inflammation of the tongue than in Poznań research, which shows that this type of lesions covered $25.8 \%$ of patients with eating disorders. Atrophic inflammation of the tongue is present in case of deficiency of vitamin B12, among others in the case of improperly balanced diet, what we are dealing with in patients with eating disorders.

\section{Conclusions}

1. No relationships were confirmed between eating disorders and the intensity of dental caries.

2. Eating disorders contribute to increased loss of dental hard tissues.

3. In women suffering from eating disorders there are more common non-specific lesions in oral cavity than in healthy women.

\section{Conflict of interest}

The authors have declared no conflict of interest.

\section{References:}

1. American Psychiatric Association: Diagnostic and Statistical Manual of Mental Disorders. 2013, Arlington, VA. American Psychiatric Association, 329-354.

2. Helström I. Oral complications in anorexia nervosa. Scand J Dent Res 1977; 85: 71-86.

3. Hurst PS, Lacey JH, Crisp AH. Teeth, vomiting and diet: study of the dental characteristics of seventeen anorexia nervosa patients. Postgrad Med J 1977; 53: 298-305.

4. Rusyan E, Słowińska SM, Dubielecka M, Jakubczyk A. Stan zdrowia jamy ustnej pacjentów z anoreksją. Mag Stom 2005; 166: 32-34.

5. Buczkowska-Radlińska J, Kaczmarek W, Tyszler Ł, Mikołajczyk E, Frączak B. Stan zębów u pacjentek z zaburzeniami odżywiania się. Annales Academiae Medicae Stetinensis 2007; 53: 90-93.

6. Daszkowska M., Rybarczyk-Townsend E., Wochna-Sobańska M.: Ocena stanu zdrowia jamy ustnej u pacjentek z zaburzeniami odżywiania. Czas Stomatol 2008; 61: 88-96.

7. Paszyńska E, Słopień A, Węglarz M, Linden R. Parametry śliny przyusznej u pacjentów z żarłocznością psychiczną (bulimia nervosa) - kontrolowane badanie kliniczne. Psychiatr Pol 2015; 49: 709-720.

8. Paszyńska E. Indeks starcia tkanek zębów u chorych z zaburzeniami odżywiania typu bulimia nervosa. Czas Stomatol 2006; 59: 19-25.

9. Paszyńska E, Słopień A, Ślebioda Z, Dyszkiewicz-Konwińska M, Węglarz M, Rajewski A. Ocena makroskopowa błony śluzowej jamy ustnej i analiza pH śliny u pacjentów z jadłowstrętem psychicznym. Psychiatr Pol 2014; 48: 453-464.

10. Paszyńska E, Słopień A, Osińska A, Dmitrzak-Węglarz M, Rajewski A, Surdacka A. Zmiany w jamie ustnej w przebiegu intensywnych wymiotów u pacjentki z zaburzeniem wegetatywnym występującym pod postacią somatyczną - opis przypadku. Psychiatr Pol 2016; 50: 521-531.

\section{Correspondence address}

Jolanta Szymańska

Chair and Department of Paedodontics, Medical University of Lublin, Poland

ul. Karmelicka 7, 20-081 Lublin

e- mail: szymanska.lublin@gmail.com

tel.: +48601165205

Otrzymano: 10.05.2016

Zrecenzowano: 18.05.2016

Przyjęto do druku: 25.05.2016 